\title{
Primates and Rodent Models for Dementia: A Review
}

\author{
Rahul Kumar Sharma*, Harsimran Singh, Devinder Kaur, Yogesh Kumar \\ Department of Pharmacology, Amar Shaheed Baba Ajit Singh Jujhar Singh Memorial (ASBASJSM) College of Pharmacy, Bela, Ropar, Punjab, INDIA.
}

\begin{abstract}
Memory and cognitive functions are some of the most important and complex functions performed by the human brain. Any disorders which affect our memory will very much affect our lifestyle. Dementia and other cognitive dysfunctions are progressively emerging in the human race. To uncover newer drugs to cure such disorders we need better medium to understand the pathophysiological events occur during such disorders, so that we can make better approaches toward the cure. For such purpose different animal models are there. This review will uncover the most significant animal models. A thorough and critical evaluation of present rodent and primate models, their possible mechanism to cause such disorders and their role in drug discovery has been carried out. There are many possible pathological events that occur during cognitive disorders; in this
\end{abstract}

review, we try to cover them all. This review will give a complete in-site of prognosis, progression, and evaluation of newer drugs has been made. Key words: Dementia, Animal models, Cognitive dysfunctions, Neurological dysfunction, Transgenic animal model.

Correspondence

Dr. Rahul Kumar Sharma,

Department of Pharmacology, Amar Shaheed Baba Ajit Singh Jujhar Singh Memorial (ASBASJSM) College of Pharmacy, Bela, Ropar-140111, Punjab, INDIA.

Email id: buntyrahul177@gmail.com

DOI: 10.5530/ijpi.2021.3.45

\section{INTRODUCTION}

Dementia is a cognitive disorder that affects cognitive areas of the brain, which leads to impaired thinking ability, impaired memory, forgetfulness, and certain other neurological dysfunction like anxiety, depression, and other personality disorders. ${ }^{1}$ Combined all these functions affect one's social life, personal and professional life to a certain extent. A previous study estimated that currently 4.5 million people are suffering from dementia in the United States alone and the count will reach up to 15 million.

There are two kinds of event occurs in body which can lead to dementia and memory defects. First are the events which occur inside the brain and second are the events that occur outside the brain. In the brain, there are certain neurodegenerative events that will further lead to dementia, like the formation of neurofibrillary tangles and $\beta$ amyloid plaques which affect the cognitive areas directly or indirectly by blocking the neurotransmission to these areas and leads to dementia. ${ }^{2}$ Outside the brain, there will be certain an event that actually occurs outside the brain but ultimately affect the cognitive and memory areas of the brain which will further lead to memory defects. These events may include certain vascular disorders which lead to impaired blood supply either to the whole brain or to certain areas; this decreased blood flow will further lead to cognitive disorders if areas that lack blood flow are cognitive areas. ${ }^{3}$ Choosing the correct animal model for evaluating drug effects is also a very crucial decision to make. There are several laboratory animals that are used for evaluating the benefits of drugs under disease conditions, but we should select animal models that mimic human disease. ${ }^{4}$ The idealanimalmodelfordementiaisthatitexhibitsthesamehistopathological, behavioral, and biochemical up and downs as humans with dementia should have. ${ }^{5}$ So far many animals are used for evaluating drugs for their beneficial effect in dementia and other cognitive disorders such as Primates (Apes and Monkeys), Rodents (Rats and Mice), worms, and flies. ${ }^{6}$ Every animal model will have their advantages over other and disadvantages from other like mice and rats are easy to handle but they do not develop plaques and tangles normally with age as humans do.
Primates are expensive to maintain but they have the exact physiology as human's have. ${ }^{4}$

In this review, we will study various models of dementia in primates and rodents Table 1 . We are specifically focusing on these animals because they have the almost same physiology as humans do normally as well as in disease conditions, it is easy to induce dementia in such animals, they are easy to maintain and they can be molded into laboratory conditions.

\section{SPONTANEOUS METHODS}

\section{Age associated models}

As age increases, memory and other cognitive impairments increase with it. This decrease in memory and cognitive abilities can also be seen in various aged experimental animals. ${ }^{6}$ These animal models can serve as an excellent tool for the study of various pathophysiological events associated with memory disorders. These models associated with older age mimics almost the same neurochemical as well as morphological alterations in the brain of Alzheimer's patient. ${ }^{3}$ As the individual grows older, the level of amyloid precursor protein and tau protein increases in cerebrospinal fluid, both of which have different neurotoxic properties. This increased level is also observed in animals as age increases. These models also have certain advantages over other models like these are natural, no chemical or surgical procedure in required for induction. Aged rats are most commonly utilized for this experimental purposes.? Apart from rats aged monkeys. ${ }^{8}$

\section{CHEMICAL INDUCED MODELS}

\section{Scopolamine induced}

Scopolamine (Hyoscine), is an alkaloid drug, which is isolated from Belladonna plant. It is used as an anti-muscarinic drug over a long time. Amnesia induced by scopolamine is senile amnesia. ${ }^{9}$ Cholinergic neurons play a very critical role in the cognitive functions of brain. In senile dementia (amnesia) there is reduction in level of cholinergic neurons in 


\section{Table 1: Animal Models of dementia.}

\begin{tabular}{|c|c|c|}
\hline S. No. & Model name & Animals utilized \\
\hline \multirow[t]{2}{*}{1.} & Spontaneous Models & \\
\hline & a) Age associated models & Rats, Monkeys \\
\hline \multirow[t]{8}{*}{2.} & Chemical induced & \\
\hline & Scopolamine induced & Rats, Mice, Monkeys \\
\hline & Alcohol induced & Rats \\
\hline & MPTP- induced & Rats, Monkeys \\
\hline & Lipopolysaccharide induced & \\
\hline & Sodium Azide induced & Mice \\
\hline & Heavy metal induced & Rats \\
\hline & & Rats \\
\hline \multirow[t]{3}{*}{3.} & Surgical methods & \\
\hline & ICV models & Rats \\
\hline & Ischemic models & Rats, Mice, Monkeys \\
\hline \multirow[t]{5}{*}{4.} & Transgenic Animal models of Dementia & Rats \\
\hline & $\mathrm{A} \beta$-tau Axis & Mice \\
\hline & Secretase Model & \\
\hline & APoE Model & \\
\hline & Axonal Transport model & \\
\hline
\end{tabular}

forebrain (basal) and there is reduction in level of cholineacetyltransferase in cortical and limbic areas of brain. ${ }^{10}$

This reduction in cholinergic neurons functions can be mimic by administering anti-cholinergic agents like scopolamine in various laboratory animals. These cholinergic agents can induce memory loss by blocking central cholinergic receptors involved in following animals:

(a) Rodents are very convenient experimental animals. Rats are commonly used in this model. Scopolamine can be given intraperitoneally ( 0.3 or $0.5 \mathrm{mg} / \mathrm{kg}$ ) to reduce learning and memory. ${ }^{6}$

(b) Mice can also serve as a novel model to understand cholinergic changes in the brain during dementia. Scopolamine $(0.01$ to $0.1 \mathrm{mg} / \mathrm{kg}$ ) subcutaneously is given $1 \mathrm{hr}$ prior to experimentation to induce a temporary reduction in memory as well as learning. Scopolamine ( $2 \mathrm{mg} / \mathrm{kg}$ ) subcutaneously can be given for 10 days for a reduction in memory as well as learning. ${ }^{11}$

(c) Monkeys or primates are used because of their anatomical and physiological similarities with humans. Scopolamine given at a dose of 0.01-0.04 mg/kg intramuscular can induce dose-dependent memory deficit in rhesus monkey study. ${ }^{12}$

\section{Alcohol induced dementia}

Alcohol is the world's highly consumed drug, can act as a psychoactive drug, but has a toxic profile, consumption of alcohol can leads to temporary or permanent organ damage or death in a dose-dependent manner. Ethanol consumption can lead to peripheral as well as central nervous system toxicity, which can further results in cognitive deficits such as learning and memory impairment. The proper mechanism of alcohol-induced neurotoxicity is still uncovered, but several explanations have been proposed. Among these is excitotoxicity which can be caused by excessive neurotransmitter release, oxidative stress which further leads to free radical generation which will result in neuronal damage. ${ }^{13}$

In a first rat model of alcohol-induced dementia, Alcohol gave by oral gavage of $10 \mathrm{~g} / \mathrm{kg}$ of $35 \%$ (v/v) ethanol (b.i.d) in distilled water for 10 weeks, can induce cognitive dysfunctions. ${ }^{14}$

In a second rat model, increasing concentrations of alcohol in drinking water until a $20 \%$ solution reached can be administered to rats to induce dementia. After 8 weeks of administration of alcohol as the only source of fluid, rats should be given access to water for $1 \mathrm{~h} /$ day, and $20 \%$ alcohol for the remaining $23 \mathrm{hr}$. The solution of alcohol should be sweetened with sucrose $(8.75 \mathrm{mg} / \mathrm{ml})$ to mask its bitterness, so that stable consumption (average $20 \mathrm{ml} / \mathrm{rat} / \mathrm{day}$ ) of alcohol can be maintained for the rest of the 28 weeks treatment period, with an average intake of $4.0-8.5 \mathrm{~g} / \mathrm{kg} /$ day. $^{15}$

\section{MPTP Induced Dementia}

1-methyl-4-phenyl-1, 2, 3, 6-tetrahydropyridine (MPTP) is a neurotoxin which is specialized in selective damage to dopaminergic cells in the substantia nigra pars compacta. It is considered as a most reliable animal model of Parkinson's disease in rodents and primates. Administration of MPTP into the substantia nigra pars compacta results in induction of similar pathophysiological events that are seen in Parkinson's disease. Like, degeneration of Dopaminergic neurons, neuroinflammation, and motor dysfunctioning, it will also lead to glutamate-induced excitotoxicity. Cognitive impairment can often be seen in MPTP-lesioned rats as well as in monkeys, thus both rodents and primates can serve as models of Parkinson's disease Dementia. ${ }^{16}$

\section{MPTP model of dementia in monkeys}

MPTP can successfully affect cognitive functions in monkeys. MPTP can be administered intravenously in doses ranging from $0.05 \mathrm{mg} / \mathrm{kg}$ at the start of the study to $0.20 \mathrm{mg} / \mathrm{kg}$. Animals receive cumulative doses of up to $60 \mathrm{mg}$ over periods up to one year should be evaluated for Parkinson's Disease Dementia. ${ }^{17}$

\section{Lipopolysaccharide induced dementia}

Lipopolysaccharide is a cell wall component of gram -ve bacteria. Peripheral or central administration of LPS can induce neuroinflammation in animals. ${ }^{18}$ LPS will cause neuroinflammation by activating glial cells, which will lead to synthesis and secretion of neuro-active and neurotoxic molecules, including cytokines, like interleukins (IL-1 IL-2, IL-6), TNF- $\alpha$, and IFN- $\gamma \cdot{ }^{19}$ Among all the cytokines released due to glial cells. Interleukin-2 (IL-2) has been suggested to act as a neuromodulator in the brain. ${ }^{20} \mathrm{IL}-2$ is also known to induce several behavioral changes, including memory impairment. ${ }^{21}$ LPS in addition will further lead to cause oxidative stress by initiating the formation of reactive oxygen intermediates and nitric oxide. ${ }^{22}$ These two are further responsible for the production of reactive oxygen as well as nitrogen species centrally. ${ }^{23}$ All these pathophysiological changes in the brain can lead to neurotoxicity, which will further induce dementia in animals. ${ }^{24}$

Mice can be challenged with a single dose of LPS ( $1 \mathrm{mg} / \mathrm{kg}$; i.p.), followed by an equivalent volume of isotonic saline (vehicle of drug or drug) for 28 days for induction of dementia. ${ }^{25}$

\section{Sodium Azide induced dementia}

Sodium azide is an inorganic compound with the formula NaN3. Chronic (2-3 weeks) subcutaneous (s.c.) administration of sodium azide is supposed to induce chemical hypoxic situations and reduce the energy production in the mitochondria by causing oxidative stress by producing oxygen radicals. Chronic $\mathrm{NaN}_{3}$ delivery is supposed to affect the cortical, hippocampal areas, mesencephalic reticular formation, and central amygdala regions of the brain. These regions are responsible for memory and learning functions. Damage to these areas will lead to learning and memory deficits. ${ }^{6}$ Rats treated with various doses of sodium azide (24- $51 \mathrm{mg} / \mathrm{kg}$ per day) will induce cognitive impairment. ${ }^{26}$

\section{Aluminium induced dementia}

The presence of aluminum in the brain is supposed to be involved in various neurodegenerative disorders including Alzheimer's disease. 
Previous studies suggest that the mechanism of aluminum-induced neuro-toxicity through oxidative stress and neuro-inflammatory events. Aluminum is widely present in our environment; it is a constituent of cooking utensils and various drugs (antacids and antiperspirants). From these mediums, it gets accumulated in our body through food, air, and water. ${ }^{27}$

Animals administered with aluminum and its salts have developed $\mathrm{AD}$-like neurodegenerative disorders because aluminum will increase the $\mathrm{A} \beta$ proteins, increase the hyper-phosphorylated tau-protein, degradation of cholinergic neurons in various brain regions, trigger the neuro-inflammation, and cause oxidative damage. Dementia in rats can be induced by the administration of $\mathrm{AlCl} 3(10 \mathrm{mg} / \mathrm{kg}$, i.p.) for 20 consecutive days. ${ }^{28} \mathrm{AlCl} 3$ at a dose of $50 \mathrm{mg} / \mathrm{kg} /$ day in drinking water for 5 weeks can also induce dementia in rats. ${ }^{29}$

\section{SURGICAL MODELS}

\section{ICV models}

\section{Streptozocine-ICV model in rats}

STZ is a drug which is selectively toxic for insulin producing and secreting cells. It effectively induces toxicity peripherally as well as centrally. Intracerebroventricular administration of STZ impairs the Insulin and Insulin receptor system. Previous research in AD pointed towards involvement of the impaired glucose utilization, mitochondrial dysfunction, reduced ATP production, and energy dysregulation. These pathophysiological events are key consideration of the hypothesis that these abnormalities are mediated by desensitization of the neuronal Insulin receptors (IRs). ${ }^{30}$ Apart from impairment of insulin and insulin receptor system, ICV-STZ will produce neuronal damage by causing oxidative stress through production of ROS and RNS, abnormal phosphorylation of Tau- protein, and accumulation of $A \beta$ in various areas of brain which are involved in memory and learning. ${ }^{6}$

Stereotaxic apparatus should be used to directly inject the STZ in brain. An experimental rat model should be developed using Streptozotocin (STZ) administered intracerebroventricularly (ICV) in dose $3 \mathrm{mg} / \mathrm{kg}$. Rats should be anaesthetized with chloral hydrate $(300 \mathrm{mg} / \mathrm{kg}$, i.p.). The head should be positioned on the stereotaxic frame and mid line sagittal incision should be made in the scalp. Burr holes should be drilled in the skull on both the sides over the lateral ventricles using the coordinates, $0.8 \mathrm{~mm}$ posterior to bregma, $1.5 \mathrm{~mm}$ lateral to sagittal suture, $3.6 \mathrm{~mm}$ beneath the surface of the brain. ${ }^{30}$

\section{MPTP-ICV model in rats}

Anaesthize the rats using Zoletil (20 mg/kg, i.p.), then MPTP-HCl (1 $\mu \mathrm{mol}$ in $2 \mu \mathrm{l}$ of saline) should be infused bilaterally into the SNc (Substantia Nigra compacta), using coordinates: AP: $-5.0 \mathrm{~mm}, \mathrm{ML}: \pm 2.0 \mathrm{~mm}$, $\mathrm{DV}:-7.7 \mathrm{~mm}$ from the bregma, midline, and skull surface, respectively. Immediately after surgery, penicillin-G procaine $(0.2 \mathrm{ml}, 20,000 \mathrm{IU})$ should be injected intramuscularly to rats to avoid infection, then they will be housed individually in plastic cages for a week, afterwards they will be returned to their home cages. $10 \%$ sucrose solution should be provided ad libitum to prevent weight loss after surgery and reduce mortality for 5 days from surgery. ${ }^{31}$

\section{Ibotenic Acid-ICV model in rats}

Bilateral injections of Ibotenic acid into basal forebrain leads to formation of lesions which will further cause memory impairment in rats. Rats should be anesthetized with sodium pentobarbital (45 mg/kg i.p.) and placed in a stereotaxic apparatus. Injection of Ibotenic acid should be given in basal forebrain with the help of an injection needle connected to a micro syringe, by following the coordinate's $1.5 \mathrm{~mm}$ posterior, $2.8 \mathrm{~mm}$ bilateral to the bregma, $7.3 \mathrm{~mm}$ below the dura. Ibotenic acid should be dissolved in $50 \mathrm{mM} \mathrm{Na}$ phosphate buffer at a concentration, and then $0.5 \mathrm{ml}$ ( $6 \mu \mathrm{g}$ per side) should be infused for $5 \mathrm{~min}$. One week later, the contralateral side is treated in the same manner. ${ }^{17}$

\section{Ischemic models}

Various ischemic approaches can be used to induce vascular dementia in various experimental animals like rats and monkeys. Vascular dementia is a progressive disease that affects cognitive and learning abilities. Ischemia induce multiple pathophysiological events that lead to neurotoxicity such as excitotoxicity, increased calciuminflux, oxidativeand nitrative stress, inflammation and apoptosis..$^{32}$ There are various ischemic models which can be utilised to induce vascular dementia. Some of them are following:

\section{Bilateral Common Carotid Artery Occlusion model}

Animals should be anaesthetized with chloral hydrate $(400 \mathrm{mg} / \mathrm{kg}$, i.p.) A midline incision will be made on neck. Separate the thymus gland which will be visible after making the incision. Both common carotid arteries should be identified and freed from surrounding tissue. A thread should passed below each carotid artery. Do not tie the thread, apply the weight on the thread, so that it will occlude the arteries. Maintain it same to induce ischemic situation. After $10 \mathrm{~min}$, weight on the thread should be removed to allow the reflow of blood through carotid arteries. The incision made should be sutured back in layer to layer. The sutured area should be cleaned afterwards with $70 \%$ ethanol and anti-biotic (Neosporin) dusting powder should be sprayed over the sutured area. Body temperature of mice should be maintained at $37^{\circ} \mathrm{C}$ by heated platform throughout surgical procedure $24 \mathrm{hr}$ after the ischemia reperfusion injury animals will be evaluated for potency of drugs. ${ }^{33}$

\section{Vessel occlusion model}

In four vessel occlusion model both common carotid arteries and both vertebral arteries should be occluded. In this model both vertebral arteries should be permanently occluded. ${ }^{33}$ Now a days there are several modifications which are made with this model like, the vertebral arteries should be occluded permanently or for $15 \mathrm{~min}^{34}$

\section{Unilateral common carotid artery occlusion model}

In this model, one among the two common carotid artery should be permanently ligated using a suture. ${ }^{35} \mathrm{~A}$ unilateral common carotid artery occlusion (UCCAO) in the rat causes minor changes in cerebral blood flow $(\mathrm{CBF})$ in the ipsilateral hemisphere ${ }^{36-39}$ In rats, a combination of systemic hypoxia and UCCAO causes ischemic brain damage. This raises the possibility that the combination of HS (hemorrhagic shock) and UCCAO may also cause neurological damage. ${ }^{40}$

\section{TRANSGENIC ANIMAL MODELS OF DEMENTIA}

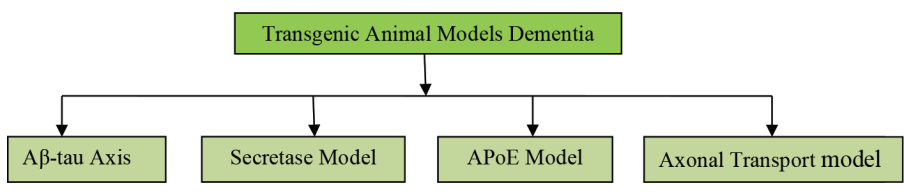

\section{A $\beta$-tau Axis model}

The amyloid plaque has a major component in dementia which is $4 \mathrm{kDa}$ polypeptide which is also called as $A \beta$-Protein that is a soluble product and secreted normally. There are two isoforms of $A \beta$ - protein ( $A \beta 41$ and $A \beta 42)$. In the case of Dementia, there is an elevation in $A \beta 42$ levels. ${ }^{41}$ The abnormal APP process leads to excess insoluble isoforms of $A \beta$-protein mainly $A \beta 42$ causes the formation of aggregates having amyloid protein in the form of oligomers. Which are more toxic to neurons. ${ }^{42,43}$ 
The first transgenic rat model of dementia resulted in intracellular $A \beta$ accumulation but there is no senile plaque. According to the reports, animal models expressing human amyloid precursor protein (APP), amyloid $\beta(\mathrm{A} \beta)$ both of which carrying familial dementia gene mutation. ${ }^{44}$ Transgenic mice harboring APP mutation generated as a model of dementia. ${ }^{45}$ Animal models were critical in providing support for amylois cascade hypothesises, which mainly claims that $\mathrm{A} \beta$ pathology causes tau pathology. Plaques and NFTs (Neurofibrillary Tangles) were the main players but the emphasis has shifted to oligomer form of $\mathrm{A} \beta$ and soluble forms of tau. The tau gene on chromosome 17 was the site of the first genetic mutation that causes FTD (Frontotemporal dementia) in humans and mutant tau gene mice have remained the primary animal model of FTP. ${ }^{46-49}$ The JNPL3 lines, which expressed human tau with the P301L mutation was one of its kind. ${ }^{50}$ Progressive more deficits, neurofibrillary tau aggregates and neuro-degeneration occur in this mice.

\section{Secretase model}

Transgenic mouse model of dementia that focus on secretase have also been developed. Transgenic mouse model have been created by some modification of $\gamma$ and $\beta$ secretase activity genetically which may result in the amyloid desposition and memory impairment. ${ }^{51}$ The expression of M146L PSEN1 is an amyloid precursor protein (APP) transgen that causes amyloid desposition can alter- secretase activity. ${ }^{52}$ It has been shown that $\beta$ secretase activity can be modulated by crossing $\beta$ amyloid converting Enzyme (BACE) APP transgene mice onto a BACE in order to reduce desposition and $A \beta$ formation. In APP/ BACE mice, overexpression of $\mathrm{BACE}$ causes increase in $\mathrm{A} \beta$ formation and deposition. ${ }^{53}$

\section{APoE model}

\section{(Apolipoprotein E)}

APoE is not a direct cause of dementia and this is by far the most powerful genetic risk factor for the diseases ${ }^{54-56}$ approximately half of all sporadic dementia patients have at least one $\varepsilon 4$ allele. ${ }^{57}$

Gila produce the majority of ApoE in the normal brain, but neuron produce APoE after injury. ${ }^{58}$ Female transgenic mice with ApoE expressing APoE from a neuron specific promoter have learning and memory deficits. ${ }^{59,60}$ The two different types of ApoE models are as follow:

\section{Tg2576×ApoE mouse model}

Tg2567 mice were crossed with murine knockout ApoE mice, which may result in complete absence of the amyloid plaques as well as amyloid deposition in the parenchyma tissue. ${ }^{61,62}$ In Tg2576 transgenic mice accumulation of $A \beta$ to the brain causes increase in the ApoE content by $60 \%$ when we compare it with control mice, resulting in accumulation of neutritic plaques positive for thioflavin s-plaque. ${ }^{63}$

\section{Pdapp $\times$ ApoE mouse model}

When $\mathrm{ApoE}_{3}$ and $\mathrm{ApoE}_{4}$ mice are knocked out and crossed with PDAPP, the $\mathrm{ApoE}_{4}$ mice developed more parenchymal amyloid plaques than the $\mathrm{ApoE}_{3}$ mice ApoE- positive PADPP mice have compact deposits scattered throughout the frontal cortex. ${ }^{64}$ In transgenic APP mice lacking ATPbinding cassette transporter $\mathrm{A} 1\left(\mathrm{ABCA}_{1}\right)$, the state of ApoE lipidation and solubility influences amyloidogensis. ${ }^{65}$

Axonal transport model: Axonal transport deficits in tau and amyloid precursor protein (APP) have been reported, and this deficit is implicated in the pathology of dementia. ${ }^{66}$ Proteins such as kinesin and dynein have been found to mediate axonal transport. ${ }^{67}$ Kinesin light chain deficiency causes increased axonal defects in $\mathrm{Klc}+/$ mice and amyloidogenic APP processing when crossed with APP transgenic mice. ${ }^{68}$

\section{CONCLUSION}

This review has covered age induced, chemically induced and surgically induced and transgenic models of dementia. We have covered all possible mechanism of action of all inducing models. In this review we have covered both rodents as well as primates, which can be possibly utilized for the experimental purpose. On one hand primates are related to human species and can possibly mirrorised the disease as it happens in humans, but experimentation with primates has some limitations like their maintenance is not easy, bigger storage facilities are required. On the other hand rodents are very much convenient option. They can mimic the disease as humans do and they are easy to maintain. Most of the work on dementia includes rodent now a days so we have a weight age toward rodents but we have also covered some important models in primates.

\section{ACKNOWLEDGEMENT}

We would like to thanks Amar Shaheed Baba Ajit Singh Jujhar Singh Memorial College of Pharmacy, Bela (An Autonomous College), for providing us moral support for writing this critical review.

\section{CONFLICT OF INTEREST}

The authors declare no conflict of interest.

\section{ABBREVIATIONS}

MPTP: 1-methyl-4-phenyl-1, 2, 3, 6-tetrahydropyridine; PDD: Parkinson's Disease Dementia; LPS: Lipopolysaccharide; STZ: Streptozocine; ICV: Intracerebroventricular; UCCAO: Unilateral Common Carotid artery Occlusion; APP: Amyloid Precursor Protein; BACE: $\beta$ Amyloid converting Enzyme; ABCA1: ATP Binding Cassette Transporter A1: APoE: Apolipoprotein E.

\section{REFERENCES}

1. Cummings BJ, Head E, Ruehl W, Milgram NW, Cotman CW. The canine as an Animal Model of Human Aging and Dementia. Neurobiol Aging. 1996;17(2):259-68. doi: 10.1016/0197-4580(95)02060-8, PMID 8744407.

2. Swerdlow RH. Pathogenesis of Alzheimer's disease. Clin Interv Aging. 2007;2(3):347-59. PMID 18044185.

3. Yue F, Lu C, AiY, Chan P, Zhang Z. Age-associated changes of cerebrospinal fluid amyloid- $\beta$ and tau in cynomolgus monkeys. Neurobiol Aging. 2014;35(7):1656-59. doi: 10.1016/j.neurobiolaging.2014.01.139, PMID 24581480.

4. Porsolt RD, Roux S, Wettstein JG. Animal models of dementia. Drug Dev Res 1995;35(4):214-29. doi: 10.1002/ddr.430350403.

5. Saito H, Togashi H, Yoshioka M, Nakamura N, Minami M, Parvez H. Animal models of vascular dementia with emphasis on stroke-prone spontaneously hypertensive rats. Clin Exp Pharmacol Physiol Suppl. 1995;22(1):S257-9. doi: 10.1111/j.1440-1681.1995.tb02906.x, PMID 9072380.

6. Neha, Sodhi RK, Jaggi AS, Singh N. Animal models of dementia and cognitive dysfunction. Life Sci. 2014;109(2):73-86. doi: 10.1016/j.Ifs.2014.05.017, PMID 25066372.

7. Gupta VK, Scheunemann L, Eisenberg T, Mertel S, Bhukel A, Koemans TS Kramer JM, Liu KS, Schroeder S, Stunnenberg HG, Sinner F, Magnes C, Pieber TR, Dipt S, Fiala A, Schenck A, Schwaerzel M, Madeo F, Sigrist SJ. Restoring polyamines protects from age-induced memory impairment in an autophagydependent manner. Nat Neurosci. 2013;16(10):1453-60. doi: 10.1038/nn.3512 PMID 23995066.

8. Bartus RT, Dean RL, Beer B. Neuropeptide effects on memory in aged monkeys. Neurobiol Aging. 1982;3(1):61-8. doi: 10.1016/0197-4580(82)90062-8, PMID 6124893.

9. Flood JF, Cherkin A. Scopolamine effects on memory retention in mice: A model of Dementia? Behav Neural Biol. 1986;45(2):169-84. doi: 10.1016/s01631047(86)90750-8, PMID 3964171.

10. Ridley RM, Baker HF. A critical evaluation of monkey models of amnesia and dementia. Brain Res Brain Res Rev. 1991;16(1):15-37. doi: 10.1016/01650173(91)90018-4, PMID 1907517.

11. Habibyar AF, Sharma N, Khurana N. PASS assisted prediction and pharmacological evaluation of hesperidin against scopolamine induced amnesia in mice. Eur $J$ Pharmacol. 2016;789:385-94. doi: 10.1016/j.ejphar.2016.07.013. PMID 27397428.

12. Rupniak NMJ, Samson NA, Steventon MJ, Iversen SD. Induction of cognitive impairment by scopolamine and noncholinergic agents in Rhesus monkeys. 
Life Sci. 1991;48(9):893-9. doi: 10.1016/0024-3205(91)90036-b, PMID 1847737.

13. Crews FT, Collins MA, Dlugos C, Littleton J, Wilkins L, Neafsey EJ, Pentney R, Snell LD, Tabakoff B, Zou J, Noronha A. Alcohol-induced neurodegeneration: when, where and why? Alcohol Clin Exp Res. 2004;28(2):350-64. doi: 10.1097/01. alc.0000113416.65546.01, PMID 15112943.

14. Tiwari V, Chopra K. Protective effect of curcumin against chronic alcohol-induced cognitive deficits and neuroinflammation in the adult rat brain. Neuroscience. 2013;244:147-58. doi: 10.1016/j.neuroscience.2013.03.042, PMID 23583655.

15. Hodges H, Allen Y, Sinden J, Mitchell SN, Arendt T, Lantos PL, Gray JA. The effects of cholinergic drugs and cholinergic-rich foetal neural transplants on alcohol-induced deficits in radial maze performance in rats. Behav Brain Res. 1991;43(1):7-28. doi: 10.1016/s0166-4328(05)80048-8, PMID 1677582.

16. Hsu CY, Hung CS, Chang HM, Liao WC, Ho SC, Ho YJ. Ceftriaxone prevents and reverses behavioral and neuronal deficits in an MPTP-induced animal model of Parkinson's disease dementia. Neuropharmacology. 2015;91:43-56. doi: 10.1016/..neuropharm.2014.11.023, PMID 25499022.

17. Vogal HG. Drug discovery and evaluation pharmacological assays. Berlin, Heidelberg: Springer-Verlag; 2002. p. 619-43.

18. Hauss-Wegrzyniak B, Lukovic L, Bigaud M, Stoeckel ME. Brain inflammatory response induced by intracerebroventricular infusion of lipopolysaccharide: an immunohistochemical study. Brain Res. 1998;794(2):211-24. doi: 10.1016/ s0006-8993(98)00227-3, PMID 9622633

19. Labuzek K, Kowalski J, Gabryel B, Herman ZS. Chlorpromazine and loxapine reduce interleukin-1 beta and interleukin-2 release by rat mixed glial and microglial cell cultures. Eur Neuropsychopharmacol. 2005;15(1):23-30. doi: 10.1016/j.euroneuro.2004.04.002, PMID 15572270.

20. Nisticò G, De Sarro G. Is interleukin 2 a neuromodulator in the brain? Trends Neurosci. 1991;14(4):146-50. doi: 10.1016/0166-2236(91)90086-a, PMID 1710852.

21. Lacosta S, Merali Z, Anisman H. Influence of acute and repeated interleukin-2 administration on spatial learning, locomotor activity, exploratory behaviors, and anxiety. Behav Neurosci. 1999;113(5):1030-41. doi: 10.1037//07357044.113.5.1030, PMID 10571485.

22. Kawashima K, Fujii T. The lymphocytic cholinergic system and its biological function. Life Sci. 2003;72(18-19):2101-9. doi: 10.1016/s0024-3205(03)00068-7, PMID 12628464.

23. Nizri E, Hamra-Amitay YH, Sicsic C, Lavon I, Brenner T. Anti-inflammatory properties of cholinergic up-regulation: a new role for acetylcholinesterase inhibitors. Neuropharmacology. 2006;50(5):540-7. doi: 10.1016/..neuropharm.2005.10.013, PMID 16336980.

24. Reale M, larlori C, Gambi F, Feliciani C, Salone A, Toma L, DeLuca G, Salvatore M, Conti P, Gambi D. Treatment with an acetylcholinesterase inhibitor in Alzheimer patients modulates the expression and production of the pro-inflammatory and anti-inflammatory cytokines. J Neuroimmunol. 2004;148(1-2):162-71. doi: 10.1016/j.jneuroim.2003.11.003, PMID 14975597.

25. Jacewicz M, Czapski GA, Katkowska I, Strosznajder RP. Systemic administration of lipopolysaccharide impairs glutathione redox state and object recognition in male mice. The effect of PARP-1 inhibitor. Folia Neuropathol. 2009;47(4):321-8. PMID 20054784.

26. Szabados T, Dul C, Majtényi K, Hargitai J, Pénzes Z, Urbanics R. A chronic Alzheimer's model evoked by mitochondrial poison sodium azide for pharmacological investigations. Behav Brain Res. 2004;154(1):31-40. doi: 10.1016/j. bbr.2004.01.016, PMID 15302108.

27. Luo Y, Nie J, Gong QH, LuYF, Wu Q, Shi JS. Protective effects of icariin against learning and memory deficits induced by aluminium in rats. Clin Exp Pharmacol Physiol. 2007;34(8):792-5. doi: 10.1111/j.1440-1681.2007.04647.x, PMID 17600559.

28. Khan KA, Kumar N, Nayak PG, Nampoothiri M, Shenoy RR, Krishnadas N, Rao CM, Mudgal J. Impact of caffeic acid on aluminium chloride-induced dementia in rats. J Pharm Pharmacol. 2013;65(12):1745-52. doi: 10.1111/jphp.12126, PMID 24236984

29. Jyoti A, Sharma D. Neuroprotective role of Bacopa monniera extract against aluminium- induced oxidative stress in the hippocampus of rat brain. NeuroToxicology. 2006;27(4):451-7. doi: 10.1016/j.neuro.2005.12.007, PMID 16500707.

30. Rai S, Kamat PK, Nath C, Shukla R. Glial activation and post-synaptic neurotoxicity: the key events in Streptozotocin (ICV) induced memory impairment in rats. Pharmacol Biochem Behav. 2014;117:104-17. doi: 10.1016/j.pbb.2013.11.035, PMID 24333387.

31. Ho YJ, Ho SC, Pawlak CR, Yeh KY. Effects of d-cycloserine on MPTP-induced behavioral and neurological changes: potential for treatment of Parkinson's disease dementia. Behav Brain Res. 2011;219(2):280-90. doi: 10.1016/j. bbr.2011.01.028, PMID 21262271.

32. Venkat $P$, Chopp M, Chen J. Models and mechanisms of vascular dementia. Exp Neurol. 2015;272:97-108. doi: 10.1016/j.expneurol.2015.05.006, PMID 25987538.

33. Singh $\mathrm{H}$, Bansal N. Neuroprotective activity of Cordia dichotoma extract in mouse model of stroke. Ethnopharmacology. 2016;4:1-7.

34. Neto CJ, Paganelli RA, Benetoli A, Lima KC, Milani H. Permanent, 3-stage, 4-vessel occlusion as a model of chronic and progressive brain hypoperfusion in rats: a neurohistological and behavioral analysis. Behav Brain Res.
2005;160(2):312-22. doi: 10.1016/j.bbr.2004.12.016, PMID 15863227.

35. Yoshizaki K, Adachi K, Kataoka S, Watanabe A, Tabira T, Takahashi K, Wakita H. Chronic cerebral hypoperfusion induced by right unilateral common carotid artery occlusion causes delayed white matter lesions and cognitive impairment in adult mice. Exp Neurol. 2008;210(2):585-91. doi: 10.1016/j.expneurol.2007.12.005, PMID 18222425.

36. Coyle P, Panzenbeck MJ. Collateral development after carotid artery occlusion in Fischer 344 rats. Stroke. 1990;21(2):316-21. doi: 10.1161/01.str.21.2.316, PMID 2305409.

37. De Ley G, Nshimyumuremyi JB, Leusen I. Hemispheric blood flow in the rat after unilateral common carotid occlusion: evolution with time. Stroke. 1985;16(1):69-73. doi: 10.1161/01.str.16.1.69, PMID 3966269.

38. Salford LG, Siesjö BK. The influence of arterial hypoxia and unilateral carotid artery occlusion upon regional blood flow and metabolism in the rat brain. Acta Physiol Scand. 1974;92(1):130-41. doi: 10.1111/j.1748-1716.1974.tb05729.x, PMID 4416312.

39. Bronner G, Mitchell K, Welsh FA. Cerebrovascular adaptation after unilateral carotid artery ligation in the rat: preservation of blood flow and ATP during forebrain ischemia. J Cereb Blood Flow Metab. 1998;18(1):118-21. doi: 10.1097/00004647-199801000-00012, PMID 9428312.

40. Rice JE 3rd, Vannucci RC, Brierley JB. The influence of immaturity on hypoxicischemic brain damage in the rat. Ann Neurol. 1981;9(2):131-41. doi: 10.1002/ ana.410090206, PMID 7235629.

41. Golde TE, Eckman CB, Younkin SG. Biochemical detection of Abeta isoforms: implications for pathogenesis, diagnosis, and treatment of Alzheimer's disease. Biochim Biophys Acta. 2000;1502(1):172-87. doi: 10.1016/s0925-4439(00)00043-0, PMID 10899442

42. Kirkitadze MD, Bitan G, Teplow DB. Paradigm shifts in Alzheimer's disease and other neurodegenerative disorders: the emerging role of oligomeric assemblies. J Neurosci Res. 2002;69(5):567-77. doi: 10.1002/jnr.10328, PMID 12210822.

43. Kayed R, Head E, Thompson JL, Mclntire TM, Milton SC, Cotman CW, Glabe CG. Common structure of soluble amyloid oligomers implies common mechanism of pathogenesis. Science. 2003;300(5618):486-89. doi: 10.1126/science.1079469, PMID 12702875.

44. 44. Balducci C. Forloni G. APP transgenic mice: their use and limitations. NeuroMolecular Med 898. 2011;13(2):117-37. doi: 10.1007/s12017-010-8141-7, PMID 21152995. Balducci C, Forloni G. APP transgenic mice: their use and limitations. NeuroMolecular Med 898. 2011;13(2):117-37. doi: 10.1007/s12017-010-8141-7, PMID 21152995.

45. Umeda T, Maekawa S, Kimura T, Takashima A, Tomiyama T, Mori H. Neurofibrillary tangle formation by introducing wild-type human tau into APP transgenic mice. Acta Neuropathol. 2014;127(5):685-98. doi: 10.1007/s00401-014-1259-1, PMID 24531886.

46. Clark LN, Poorkaj P, Wszolek Z, Geschwind DH, Nasreddine ZS, Miller B, Li D, Payami H, Awert F, Markopoulou K, Andreadis A, D'Souza I, Lee VM, Reed L, Trojanowski JQ, Zhukareva V, Bird T, Schellenberg G, Wilhelmsen KC. Pathogenic implications of mutations in the tau gene in pallido-ponto-nigral degeneration and related neurodegenerative disorders linked to chromosome 17. Proc Natl Acad Sci U S A. 1998;95(22):13103-7. doi: 10.1073/pnas.95.22.13103, PMID 9789048.

47. Hutton M, Lendon CL, Rizzu P, Baker M, Froelich S, Houlden H, Pickering-Brown S, Chakraverty S, Isaacs A, Grover A, Hackett J, Adamson J, Lincoln S, Dickson D, Davies $P$, Petersen RC, Stevens M, de Graaff E, Wauters E, van Baren J, Hillebrand M, Joosse M, Kwon JM, Nowotny P, Che LK, Norton J, Morris JC, Reed LA, Trojanowski J, Basun H, Lannfelt L, Neystat M, Fahn S, Dark F, Tannenberg T, Dodd PR, Hayward N, Kwok JB, Schofield PR, Andreadis A, Snowden J, Craufurd D, Neary D, Owen F, Oostra BA, Hardy J, Goate A, van Swieten J, Mann D, Lynch T, Heutink P. Association of missense and 5 '-splice-site mutations in tau with the inherited dementia FTDP-17. Nature. 1998;393(6686):702-5. doi: 10.1038/31508, PMID 9641683.

48. Poorkaj P, Bird TD, Wijsman E, Nemens E, Garruto RM, Anderson L, Andreadis A Wiederholt WC, Raskind M, Schellenberg GD. Tau is a candidate gene for chromosome 17 frontotemporal dementia. Ann Neurol. 1998;43(6):815-25. doi: 10.1002/ana.410430617, PMID 9629852

49. Spillantini MG, Murrell JR, Goedert M, Farlow MR, Klug A, Ghetti B. Mutation in the tau gene in familial multiple system tauopathy with presenile dementia. Proc Natl Acad Sci U S A. 1998;95(13):7737-41. doi: 10.1073/pnas.95.13.7737، PMID 9636220

50. Lewis J, McGowan E, Rockwood J, Melrose H, Nacharaju P, Van Slegtenhorst M, Gwinn-Hardy K, Paul Murphy M, Baker M, Yu X, Duff K, Hardy J, Corral A, Lin WL, Yen SH, Dickson DW, Davies P, Hutton M. Neurofibrillary tangles, amyotrophy and progressive motor disturbance in mice expressing mutant (P301L) Tau protein. Nat Genet. 2000;25(4):402-5. doi: 10.1038/78078, PMID 10932182.

51. Götz J, Ittner LM. Animal models of Alzheimer's disease and frontotemporal dementia. Nat Rev Neurosci. 2008:9(7):532-44. doi: 10.1038/nrn2420, PMID 18568014.

52. Schmitz C, Rutten BP, Pielen A, Schäfer S, Wirths O, Tremp G, Czech C Blanchard V, Multhaup G, Rezaie P, Korr H, Steinbusch HW, Pradier L, Bayer TA. 
Hippocampal neuron loss exceeds amyloid plaque load in a transgenic mouse model of Alzheimer's disease. Am J Pathol. 2004;164(4):1495-502. doi: 10.1016/ S0002-9440(10)63235-X, PMID 15039236.

53. Willem M, Dewachter I, Smyth N, Van Dooren T, Borghgraef P, Haass C, Van Leuven F. beta-site amyloid precursor protein cleaving enzyme 1 increases amyloid deposition in brain parenchyma but reduces cerebrovascular amyloid angiopathy in aging BACE x APP[V717I] double-transgenic mice. Am J Pathol. 2004;165(5):1621-31. doi: 10.1016/s0002-9440(10)63419-0, PMID 15509532

54. Bertram L, McQueen MB, Mullin K, Blacker D, Tanzi RE. Systematic meta-analyses of Alzheimer disease genetic association studies: the AlzGene database. Nat Genet. 2007;39(1):17-23. doi: 10.1038/ng1934, PMID 17192785.

55. Farrer LA. Effects of Age, Sex, and Ethnicity on the Association Between Apolipoprotein E Genotype and Alzheimer Disease: A Meta-analysis. JAMA. 1997;278(16). doi: 10.1001/jama.1997.03550160069041.

56. Raber J, Huang Y, Ashford JW. ApoE genotype accounts for the vast majority of $A D$ risk and AD pathology. Neurobiol Aging. 2004;25(5):641-50. doi: 10.1016/j. neurobiolaging.2003.12.023, PMID 15172743.

57. Saunders AM, StrittmatterWJ, Schmechel D, George-Hyslop PH, Pericak-Vance MA, Joo SH, Rosi BL, Gusella JF, Crapper-MacLachlan DR, Alberts MJ, et al. Association of apolipoprotein E allele epsilon 4 with late-onset familial and sporadic Alzheimer's disease. Neurology. 1993;43(8):1467-72. doi: 10.1212/ wnl.43.8.1467, PMID 8350998.

58. Xu Q, Bernardo A, Walker D, Kanegawa T, Mahley RW, Huang Y. Profile and regulation of apolipoprotein $\mathrm{E}(\mathrm{ApoE})$ expression in the CNS in mice with targeting of green fluorescent protein gene to the ApoE locus. J Neurosci. 2006;26(19):4985-94. doi: 10.1523/JNEUROSCI.5476-05.2006, PMID 16687490.

59. Raber J, Wong D, Buttini M, Orth M, Bellosta S, Pitas RE, Mahley RW, Mucke L. Isoform-specific effects of human apolipoprotein $E$ on brain function revealed in ApoE knockout mice: increased susceptibility of females. Proc Natl Acad Sci U S A. 1998;95(18):10914-9. doi: 10.1073/pnas.95.18.10914 PMID 9724804.

60. Raber J, Wong D, Yu GQ, Buttini M, Mahley RW, Pitas RE, Mucke L. Apolipoprotein E and cognitive performance. Nature. 2000;404(6776):352-4. doi: 10.1038/35006165, PMID 10746713.

61. Bales KR, Verina $T$, Cummins DJ, Du Y, Dodel RC, Saura J, Fishman CE DeLong CA, Piccardo P, Petegnief V, Ghetti B, Paul SM. Apolipoprotein E is essential for amyloid deposition in the APP(V717F) transgenic mouse model of Alzheimer's disease. Proc Natl Acad Sci U S A. 1999;96(26):15233-8. doi: 10.1073/pnas.96.26.15233, PMID 10611368.

62. Bales KR, Liu F, Wu S, Lin S, Koger D, DeLong C, Hansen JC, Sullivan PM, Paul SM. Human APOE isoform-dependent effects on brain beta-amyloid levels in PDAPP transgenic mice. J Neurosci. 2009;29(21):6771-9. doi: 10.1523/JNEUROSCI.0887-09.2009, PMID 19474305.

63. Kuo YM, Crawford F, Mullan M, Kokjohn TA, Emmerling MR, Weller RO, Roher AE. Elevated A beta and apolipoprotein $E$ in $A$ betaPP transgenic mice and its relationship to amyloid accumulation in Alzheimer's disease. Mol Med. 2000;6(5):430-9. doi: 10.1007/BF03401785, PMID 10952022.

64. Fryer JD, Holtzman DM. The bad seed in Alzheimer's disease. Neuron 2005:47(2):167-8. Games. doi: 10.1016/j.neuron.2005.07.002, PMID 16039556 D. Games D, Adams D, Alessandrini R, Barbour R, Berthelette P, Blackwell C, Carr T, Clemens J, Donaldson T, Gillespie F. Alzheimer-type neuropathology in transgenic mice overexpressing $\mathrm{V} 717 \mathrm{~F}$ beta-amyloid precursor protein. Nature. 1995;373(6514):523-7. doi: 10.1038/373523a0, PMID 7845465.

65. Koldamova R, Staufenbiel M, Lefterov I. Lack of ABCA1 considerably decreases brain ApoE 1138 level and increases amyloid deposition in APP23 mice. J Biol Chem. 2005;280(1139):43224-35.

66. Higuchi $M$, Zhang $B$, Forman MS, Yoshiyama $Y$, Trojanowski JQ, Lee VM Axonal degeneration induced by targeted expression of mutant human tau in oligodendrocytes of transgenic mice that model glial tauopathies. J Neurosci. 2005;25(41):9434-43. doi: 10.1523/JNEUROSCI.2691-05.2005, PMID 16221853

67. Hirokawa N, Takemura R. Molecular motors and mechanisms of directional transport in neurons. Nat Rev Neurosci. 2005;6(3):201-14. doi: 10.1038/nrn1624, PMID 15711600.

68. Stokin GB, Lillo C, Falzone TL, Brusch RG, Rockenstein E, Mount SL, Raman R, Davies P, Masliah E, Williams DS, Goldstein LS. Axonopathy and transport deficits early in the pathogenesis of Alzheimer's disease. Science. 2005;307(5713):1282-8. doi: 10.1126/science.1105681, PMID 15731448.

Article History: Submission Date : 10-06-2021; Revised Date : 30-06-2021; Acceptance Date : 25-07-2021.

Cite this article: Sharma RK, Singh H, Kaur D, Kumar Y. Primates and Rodent Models for Dementia: A Review. Int. J. Pharm. Investigation. 2021;11(3):254-9. 